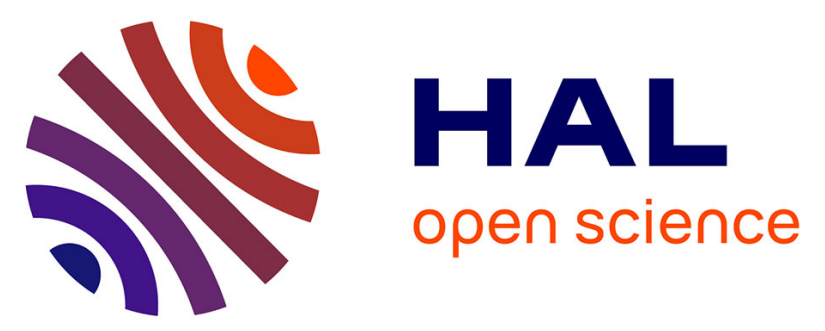

\title{
Tuning the Photophysical Properties of Push-Pull Azaheterocyclic Chromophores by Protonation: A Brief Overview of a French-Spanish-Czech Project
}

Sylvain Achelle, Julián Rodríguez-López, Filip Bureš, Françoise Robin-Le Guen

\section{To cite this version:}

Sylvain Achelle, Julián Rodríguez-López, Filip Bureš, Françoise Robin-Le Guen. Tuning the Photophysical Properties of Push-Pull Azaheterocyclic Chromophores by Protonation: A Brief Overview of a French-Spanish-Czech Project. Chemical Record, 2020, 20 (5), pp.440-451. 10.1002/tcr.201900064 . hal-02364874

HAL Id: hal-02364874

https://hal-univ-rennes1.archives-ouvertes.fr/hal-02364874

Submitted on 17 Feb 2020

HAL is a multi-disciplinary open access archive for the deposit and dissemination of scientific research documents, whether they are published or not. The documents may come from teaching and research institutions in France or abroad, or from public or private research centers.
L'archive ouverte pluridisciplinaire HAL, est destinée au dépôt et à la diffusion de documents scientifiques de niveau recherche, publiés ou non, émanant des établissements d'enseignement et de recherche français ou étrangers, des laboratoires publics ou privés. 


\section{Tuning the Photophysical Properties of Push-Pull Azaheterocyclic Chromophores by Protonation: A Brief Overview of a French- Spanish-Czech Project}

Sylvain Achelle, ${ }^{*[a]}{ }^{[u l i a ́ n ~ R o d r i ́ g u e z-L o ́ p e z, ~}{ }^{[b]}$ Filip Bureš, ${ }^{[c]}$ and Françoise Robin-le Guen ${ }^{[a]}$

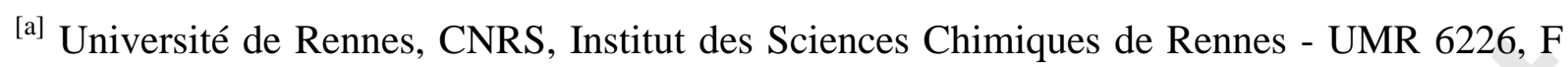
35000 Rennes, France; E-mail: sylvain.achelle@univ-rennes1.fr

[b] Área de Química Orgánica, Facultad de Ciencias y Tecnologías Químicas, Universidad de Castilla-La Mancha, Avda. Camillo José Cela 10, 13071 Ciudad Real, Spain; E-mail: julian.rodriguez@uclm.es

[c] Institute of Organic Chemistry and Technology, Faculty of Chemical Technology, University of Pardubice, Studenská 573, Pardubice 53210, Czech Republic.

\section{Graphical abstract}

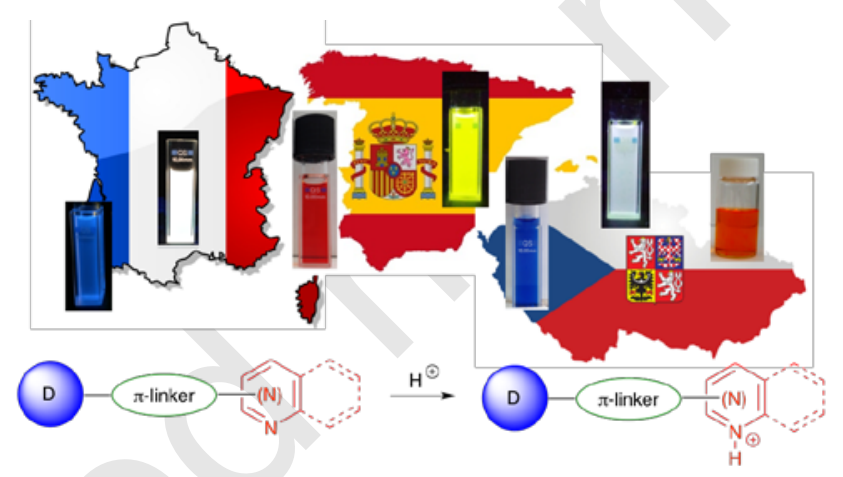

An account is provided of our studies on the effect that the addition of acid has on the photophysical properties of $\pi$-extended push-pull chromophores that incorporate azaheterocyclic rings as electron-withdrawing moieties. The work carried out to afford white light-emitting materials based on an equilibrium between neutral and protonated forms that emit complementary colors is described. 


\section{Biographical sketches}

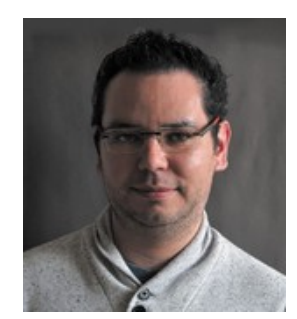

Sylvain Achelle received his PhD in organic chemistry in 2007 from INSA Rouen (France). After two post-doctoral stays at the Universidad de Castilla-La Mancha (Spain) and Institut Curie (France), he was recruited as associate professor at IUT Lannion, University of Rennes 1, in 2010. He obtained the habilitation to direct research in 2014. His main research topics include the luminescence and nonlinear optical properties of organic and organometallic heterocyclic derivatives. He has published 60 scientific articles (h-index: 23 according to Web of Science) and he is currently associate editor of the journal Dyes \& Pigments.

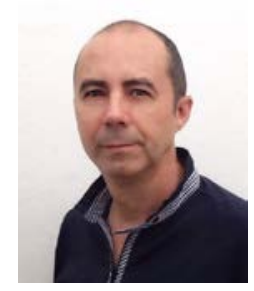

Julián Rodríguez López studied chemistry at the Universidad Complutense de Madrid (UCM) and obtained his PhD with honors (cum laude) in 1990. He was a Fulbright postdoctoral fellow at the University of Texas at Austin for one year, under the supervision of Professor Philip Magnus. After successive positions at the UCM, he joined the Universidad de Castilla-La Mancha at Ciudad Real in 1995, where he is currently full professor in organic chemistry. His research concerns the synthesis and photophysical properties of novel $\pi$ conjugated systems, especially dendrimers and diazine derivatives. 


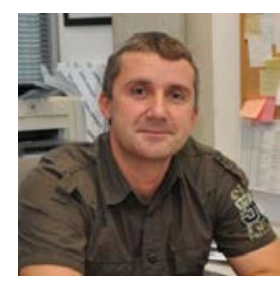

Filip Bureš studied chemistry at the University of Pardubice, where he also obtained his $\mathrm{PhD}$ in organic chemistry in 2005. He pursued (post)doctoral studies with Professor P. Knochel (LMU, Munich) and Professor F. Diederich (ETH, Zurich). In 2007 he established a working group at the Institute of Organic Chemistry, University of Pardubice, which focuses on the design and synthesis of $\pi$-conjugated molecules for miscellaneous (opto)electronic applications.

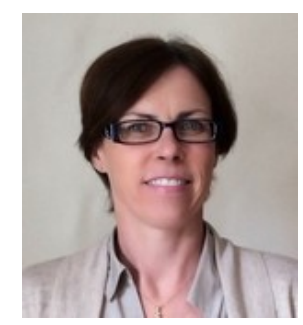

Françoise Robin-le Guen received her PhD in organometallic chemistry from the University of Bretagne Occidentale (France). She is currently full professor at IUT Lannion, University of Rennes 1 and head of the heterocyclic organometallic teams at the Chemical Sciences Institute of Rennes. Her main research topics are focused on the design of $\pi$-conjugated heterocyclic and organometallic systems for dye-sensitized solar cells, luminescence and nonlinear optics. 
Abstract: Conjugated push-pull molecules that incorporate nitrogen heterocycles as electronwithdrawing units are interesting materials because of their luminescence properties. These chromophores can be easily and reversibly protonated at the nitrogen atom of the heterocyclic ring and this can cause dramatic color changes. White and multi-color photoluminescence both in solution and in the solid state can be obtained by an accurate control of the amount of acid. Thus, with a suitable design these compounds have potential applications in the development of colorimetric $\mathrm{pH}$ sensors and the fabrication of OLEDs based on only one material. We provide here a brief overview of our collaborative efforts made in this area.

Keywords: white-light emission, push-pull chromophores, nitrogen heterocycles, protonation, photoluminescence.

\section{Introduction}

The design of push-pull chromophores has been the subject of intensive research during the past few decades. ${ }^{[1]}$ In this context, $\pi$-deficient nitrogen heterocycles such as pyridine, ${ }^{[2]}$ quinoline, ${ }^{[3]}$ diazines (pyridazine, ${ }^{[4]}$ pyrimidine, ${ }^{[5]}$ and pyrazine ${ }^{[6]}$ ), benzodiazines (quinoxaline, ${ }^{[}{ }^{\prime} 6^{]}$quinazoline, ${ }^{[}{ }^{\prime} 5^{\mathrm{c}]}$ phthalazine, ${ }^{[7]}$ etc.), phenanthroline, ${ }^{[8]}$ triazines, ${ }^{[9]}$ and tetrazines $^{[10]}$ are considered as moderate-to-strong electron withdrawing groups. Some pushpull chromophores that bear these heterocycles as the electron-attracting part exhibit intense luminescence properties. In such cases an intramolecular charge transfer (ICT) occurs and this can be easily tuned by adjusting the donor/attractor couple, the $\pi$-conjugated linker or by developing multipolar structures. ${ }^{[}{ }^{, 11]}$ An enhanced ICT leads to a bathochromic effect on the absorption spectrum whereas the effect on the emission becomes less predictable: either an increase or decrease in the intensity accompanied by a red shift, along with total quenching, can be observed depending on the structure. Engaging the electron lone pair of the nitrogen 
atoms of azaheterocycles provides a way to increase their electron-withdrawing character. In this respect, it is feasible to induce substantial changes in the photophysical properties of push-pull molecules bearing such fragments by complexation, ${ }^{[12]}$ alkylation, ${ }^{[13]}$ or reversible protonation. $^{[14]}$ This latter case is called halochromism or acidochromism. The general mechanism for the halochromic response is the redistribution of the charge density due to protonation, which promotes changes in the electronic structure. As a consequence, azaheterocyclic chromophores can be used as $\mathrm{pH}$ sensors. ${ }^{[15]}$ Likewise, a series of pyridinebased molecules were reported to be acid-triggered reversible luminescent and nonlinear optical (NLO) switches both in solution and in the solid state. ${ }^{[16]}$ The linear and NLO properties could also be tuned by coordination to metal centers. ${ }^{[16 c, d]}$ Moreover, tuning of the photo- and electroluminescence was achieved by an in situ controlled non-reversible thermal deprotonation, which can be exploited to fabricate smart thermal sensors and antifraud devices. ${ }^{[17]}$ The controlled protonation of some blue-emitting azaheterocyclic derivatives affords white photo- and electroluminescence by the formation of orange-emissive acidified species. $^{[18]}$

Over the past few decades our groups have intensively studied the photophysical properties of push-pull chromophores based on nitrogen heterocycles. In particular, we recently focused our investigations on the structure-dependent effect of protonation on the luminescence properties of such chromophores. One of our goals was to obtain efficient white light-emitting materials based on neutral and protonated forms that emit complementary colors. In this personal account, we would like to provide a brief overview of our 'FrenchSpanish-Czech’ collaborative efforts made in this direction.

\section{Pyrimidine chromophores}


The pyrimidine nucleus generally acts as a monobasic compound with $\mathrm{pK}_{\mathrm{a}} \approx 1.1$. Thus, it is a weaker base than pyridine $\left(\mathrm{pK}_{\mathrm{a}} \approx 5.2\right)$. Protonation of the first nitrogen atom leads to a marked decrease in the basicity of the second nitrogen atom due to the attractive inductive effect of the resulting quaternary nitrogen (second $\mathrm{pK}_{\mathrm{a}} \approx-6.3$ ). ${ }^{[19]}$

Although some of us described some basic information on the $\mathrm{pH}$ sensitivity of arylpyrimidine derivatives in $2008,{ }^{[20]}$ the first comprehensive study on the effects of the protonation concerns 4,6-bis(arylvinyl)pyrimidines 1-8 (Figure 1). ${ }^{[21]}$ With the exception of compound 3, which has a trifluoromethyl electron-withdrawing substituent, the addition of trifluoroacetic acid (TFA) to a $\mathrm{CH}_{2} \mathrm{Cl}_{2}$ solution of compounds 1-8 induced a dramatic color change (Figure 1). This color change was fully reversible by neutralization with a base such as $\mathrm{Et}_{3} \mathrm{~N}$ or $\mathrm{KBu}^{t} \mathrm{O}$. As far as emission is concerned, compounds substituted with moderate electron-donating groups $(\mathbf{1}, \mathbf{4}, 5$ and $\mathbf{7})$ or $\mathrm{CF}_{3}$ fragments (3) remained luminescent upon protonation and this was associated with a red-shifted emission band, a significant decrease in the Stokes shifts and, in some cases, an increase in the fluorescence quantum yield (1, $\mathbf{3}$ and 4). For stronger electron-donating groups such as $\mathrm{NPh}_{2}$ (chromophore 2) and for the dendritic structure 8, the emission was completely quenched after protonation, whereas ferrocene derivative 6 remained non-emissive in acidic media. Similarly, an acetonitrile solution of the arylvinylpyrimidine $\mathbf{9}$, which contains a dipicolylamine substituent, showed red-shifted absorption and emission quenching upon addition of TFA (Figure 1). ${ }^{[22]}$ 

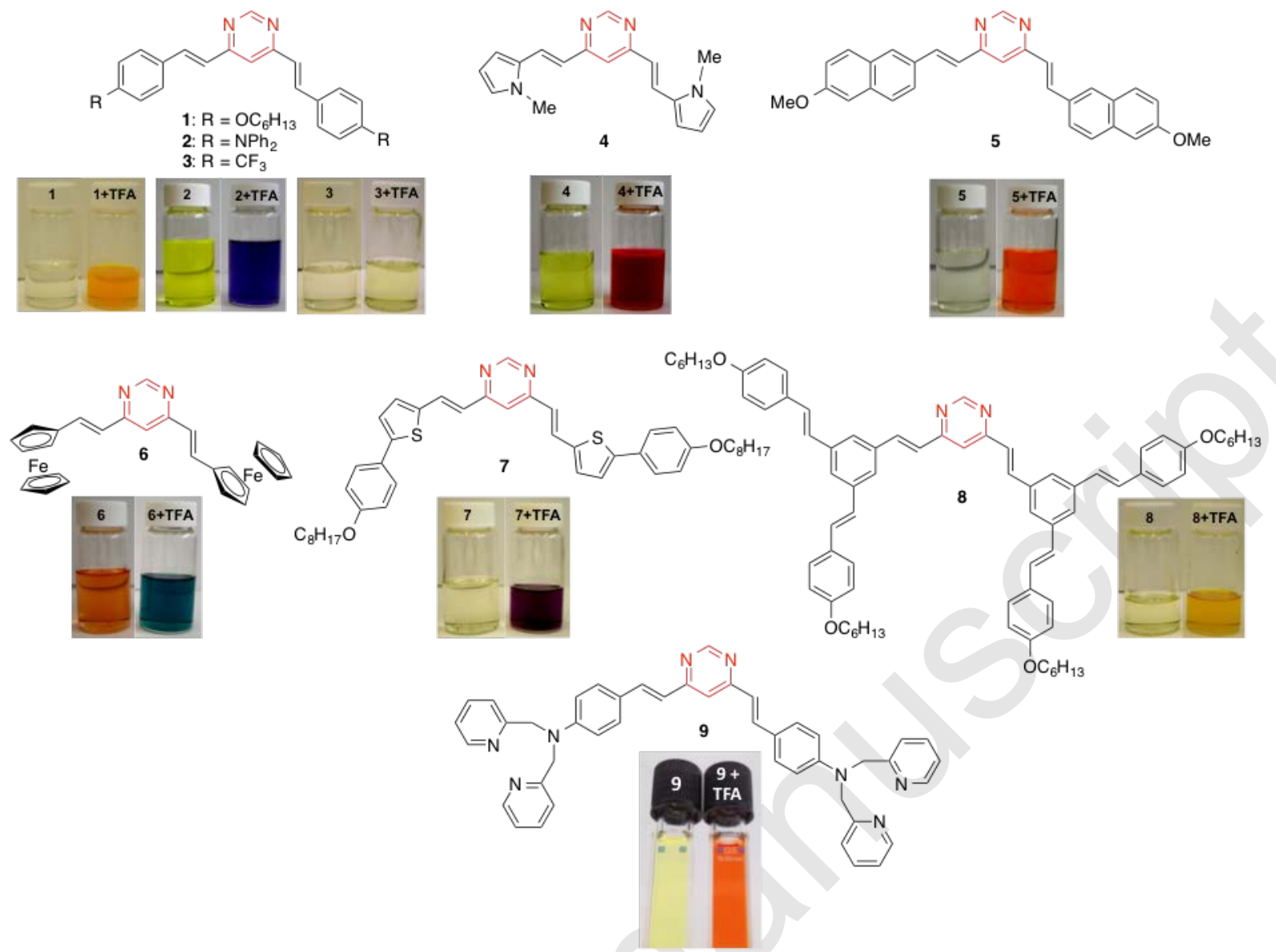

Figure 1. Color change of $\mathrm{CH}_{2} \mathrm{Cl}_{2}$ solutions of compounds 1-8 (acetonitrile solution for 9) after treatment with TFA.

4-Arylvinyl-2,6-di(pyridin-2-yl)pyrimidines ${ }^{[23]} \quad \mathbf{1 0}, \quad \mathbf{1 1}, \quad 13 \quad$ and $\quad 14, \quad 4-$ arylvinylpyrimidines 15-17, 19-22, 24, 27 and 28, and 2-arylvinylpyrimidines 29-33 (Figure 2) ${ }^{[24,25,26,27]}$ exhibited similar behavior to that found for 4,6-bis(arylvinyl)pyrimidine derivatives 1-8. Namely, THF or $\mathrm{CH}_{2} \mathrm{Cl}_{2}$ solutions of these compounds underwent a significant color change upon addition of acid (Figure 3). Whereas a red shift of the charge transfer absorption band was observed, the emission was either completely quenched for the compounds substituted with strong electron-donating amino groups $(\mathbf{1 1}, \mathbf{1 4}, \mathbf{1 6}, \mathbf{1 7}$, and 24$)$ or red-shifted for chromophores with weaker methyl, methoxy, and thiomethyl electron donors $(10,13,15,19,21$, and 22). As an example, the change in the absorption and emission spectra of a THF solution of $\mathbf{1 0}$ upon gradual addition of $p$-toluensulfonic acid ( $p$-TSA) is shown in 
Figure 4. Compound 20 remained non-emissive upon protonation. Theoretical calculations performed on compound $\mathbf{1 9}$ indicated that planarization of the structure occurs upon protonation along with reduction of the bond length alternation (BLA) value in the vinyl unit. $^{[25]}$ The most favorable site for protonation in the ground state was found at N1. It should be noted that for dimethylamino derivatives 12 and 23, as well as piperidinyl compounds 18 and 25, the protonation led to a blue-shifted absorption due to protonation of the basic amino groups. Nevertheless, this phenomenon was not observed for 2-arylvinylpyrimidines $\mathbf{3 1}$ and 33. ${ }^{[26]}$ Surprisingly, in contrast to monosubstituted triphenylamine 16 and 2,6-di(pyridin-2yl)pyrimidine analog 14, the protonated form of $\mathbf{2 6}$ remained luminescent in $\mathrm{CH}_{2} \mathrm{Cl}_{2}$ with an emission band at $570 \mathrm{~nm} .{ }^{[28]}$ This fact can be explained by a slightly reduced ICT in this case. Color change and protonation for compounds 27 and 28, with an extended $\pi$-conjugated linker, was observed at higher concentrations of TFA $\left(10^{-2}-10^{-1} \mathrm{M}\right)$ than for other diazine derivatives with shorter $\pi$-conjugated scaffolds. ${ }^{[27]}$

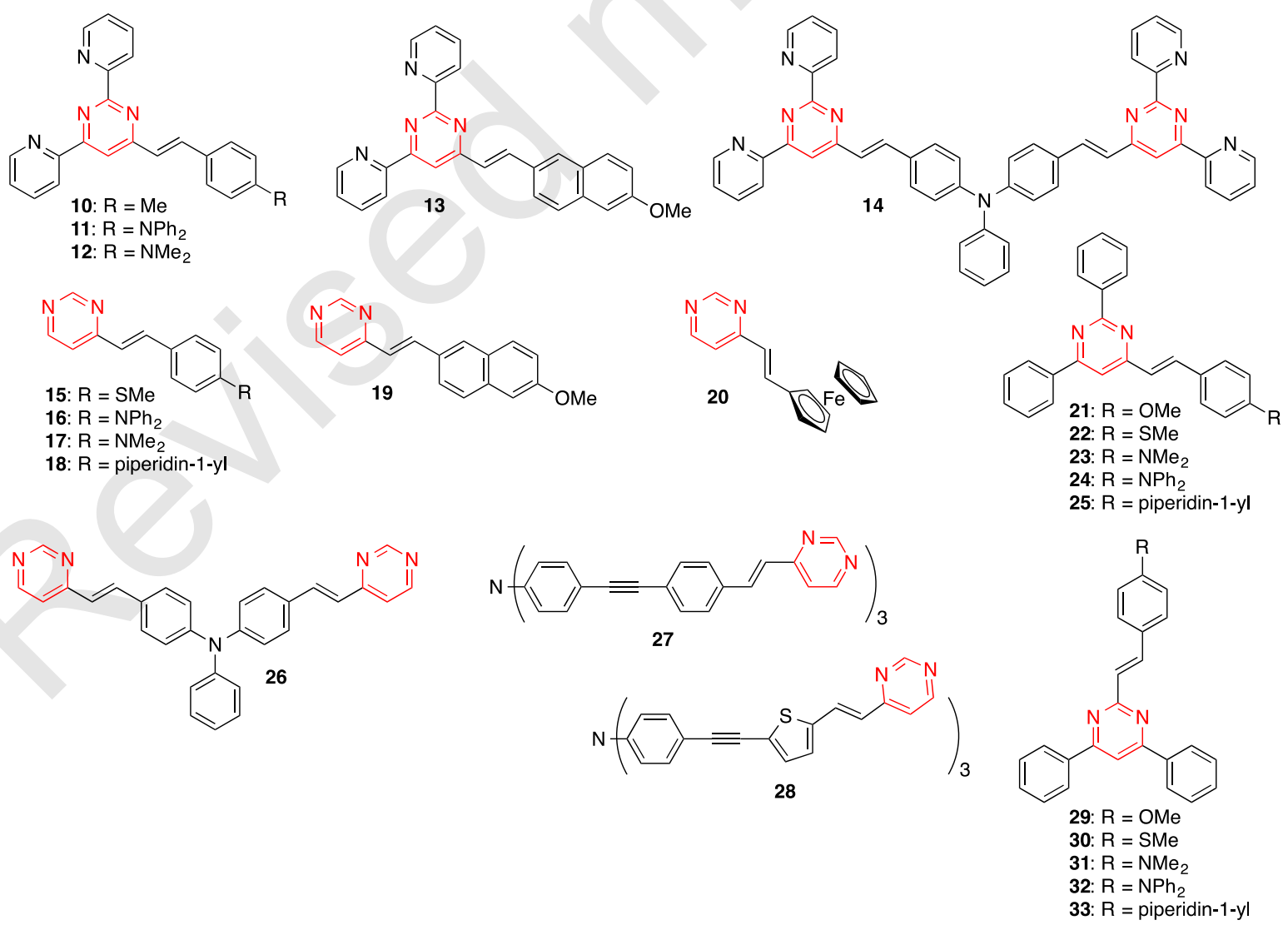

Figure 2. Chemical structures of compounds 10-33. 

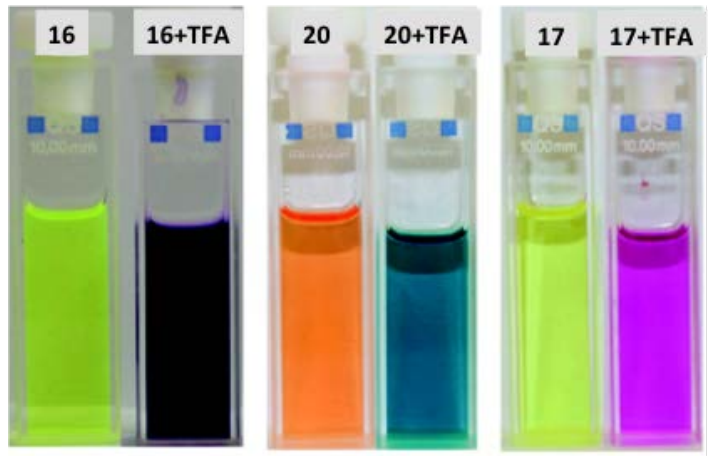

Figure 3. Color change of $\mathrm{CH}_{2} \mathrm{Cl}_{2}$ solutions of compounds 16, 20, and 17 (from left to right) ( $c=10^{-3} \mathrm{M}$ in the presence of $10^{-2} \mathrm{M}$ TFA). Adapted with permission from reference [24] (copyright 2012 American Chemical Society).
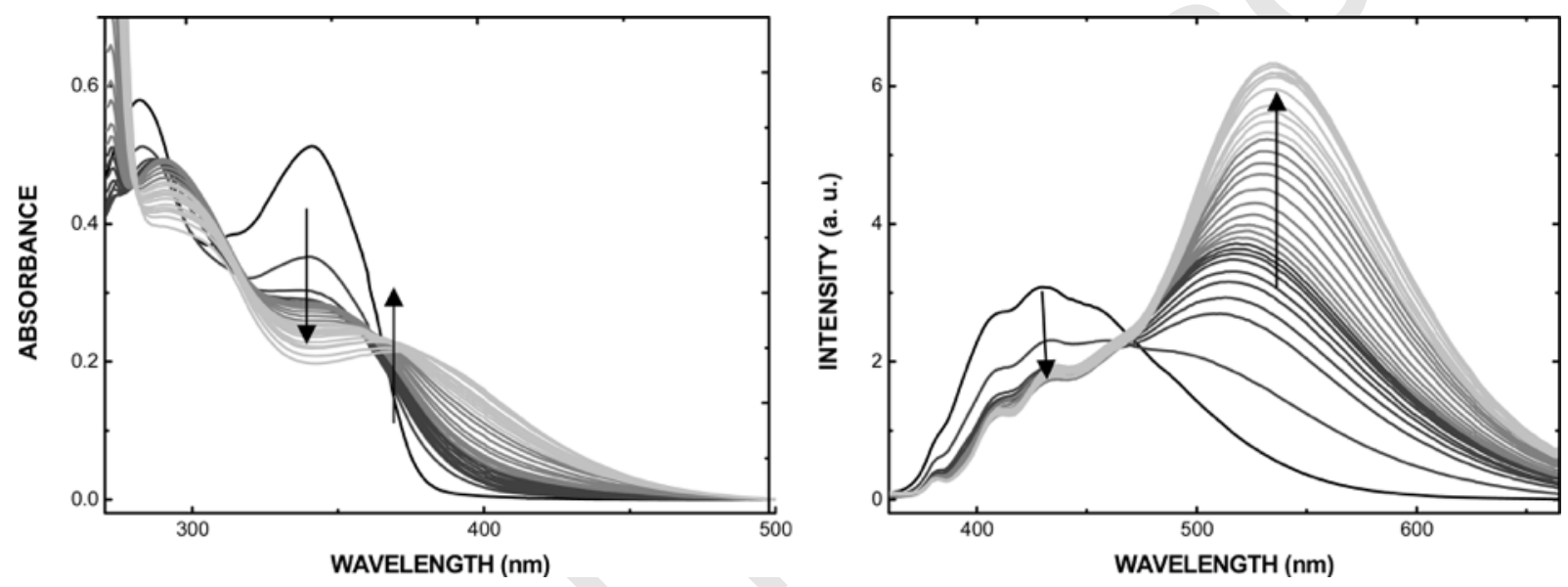

Figure 4. Changes in the absorption (left) and emission (right) spectra of $\mathbf{1 0}\left(2.0 \times 10^{-5} \mathrm{M}\right.$ in THF) upon addition of $p$-TSA $\left(7.5 \times 10^{-5} \mathrm{M}\right.$ to a large excess). Reproduced with permission from reference [23] (copyright 2011 American Chemical Society).

4-Arylvinylpyrimidine chromophores have also been incorporated into polymethyl methacrylate-based copolymers 34-36 (Figure 5). ${ }^{[29]}$ The macromolecules displayed similar photophysical properties in $\mathrm{CH}_{2} \mathrm{Cl}_{2}$ solution when compared to the free chromophores. Thus, upon adding acid, a red shift was obtained both in the absorption and emission spectra. The emission was partially (34) or totally (35) quenched for the amino-substituted compounds. 


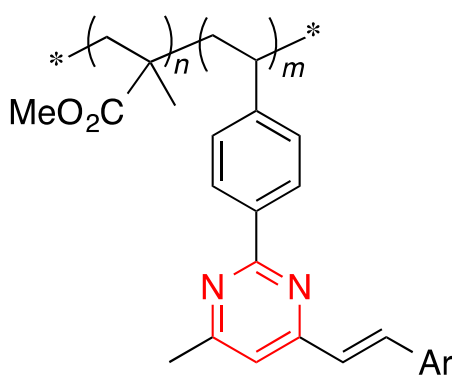

34: $\mathrm{Ar}=\longrightarrow-\mathrm{NMe}_{2}$

35: $\mathrm{Ar}=-\mathrm{NPh}_{2}$

36: $\mathrm{Ar}=$

Figure 5. Chemical structures of copolymers 34-36.

The behavior upon acidic treatment of pyranylidene derivatives 37-39 (Figure 6) depends on the $\pi$-conjugated linker. The addition of acid to compounds $\mathbf{3 7}$ and $\mathbf{3 8}$ led to a significant red shift in the absorption and this is attributed to protonation of the pyrimidine ring, with the solution remaining non-emissive ${ }^{[30]}$ Compound $\mathbf{3 9}$, with a phenylene unit in the linker, showed different behavior: a blue-shifted absorption band appeared progressively upon addition of TFA and the protonated species exhibited an intense blue emission at $450 \mathrm{~nm}\left(\Phi_{\mathrm{F}}\right.$ $=0.13$ ) attributed to the formation of a pyrylium cation.

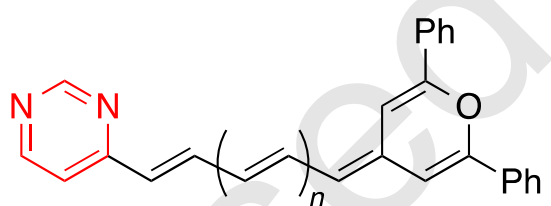

37: $n=0$

38: $n=1$<smiles>C(=C1C=C(c2ccccc2)OC(c2ccccc2)=C1)c1ccc(/C=C/c2ccccc2)cc1</smiles>

39

Figure 6. Chemical structures of pyranylidenes 37-39.

Chromophores 11 (Figure 2) and $\mathbf{4 0}$ (Figure 7) have been incorporated into pluronic F68 nanoparticles and stable aqueous colloidal solutions were obtained. ${ }^{[31]}$ The position of the absorption band of the aqueous emulsions was virtually the same as that of the chloroform solutions. On decreasing the $\mathrm{pH}$, these emulsions underwent an immediate and fully reversible color change from yellow to purple. The spectra showed the decrease of the initial 
band located at around $420 \mathrm{~nm}$ for both chromophores, together with the development of a new red-shifted band located at $480 \mathrm{~nm}$ for $\mathbf{1 1}$ and $530 \mathrm{~nm}$ for $\mathbf{4 0}$ (Figure 7). The $\mathrm{pK}_{\mathrm{a}}$ values were estimated to be 1.1 and 1.8 for $\mathbf{1 1}$ and $\mathbf{4 0}$, respectively. The 'pH switch' value between the yellow and purple forms is very low, but these nanoparticle assemblies behave as colorimetric $\mathrm{pH}$ sensors in aqueous media. It should be noted that all aqueous emulsions were non-emissive - probably due to hydrogen bonding interactions between the hydrophilic pluronic segments and/or water protons with the nitrogen atoms of the pyrimidine ring.

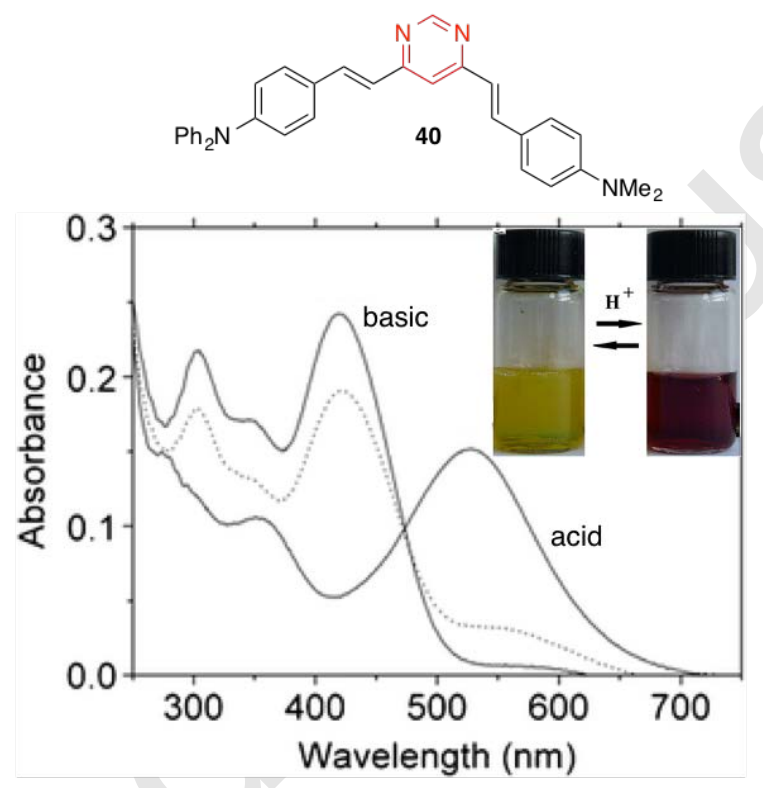

Figure 7. Absorption spectra of dilute pluronic F-68 nanoparticles incorporating chromophore 40 at acidic, basic and intermediate $\mathrm{pH}$ (dotted line). Inset: color change upon addition of $\mathrm{HCl}$. Adapted with permission from reference [31] (copyright 2012 Springer).

The change in the color emission of a $\mathrm{CH}_{2} \mathrm{Cl}_{2}$ solution of the tristyrylpyrimidine $\mathbf{4 1}$ upon addition of $(1 S)-(+)-10$-camphorsulfonic acid (CSA) is illustrated in Figure $8 .^{[32]}$ The photoluminescence spectra are characterized by the progressive disappearance of the band of the neutral form at $441 \mathrm{~nm}$, which is accompanied by the progressive appearance of a new red-shifted band at $540 \mathrm{~nm}$ that corresponds to the monoprotonated species. The neutral form emits dark blue light whereas the protonated form emits green light. A mixture of the two produces cyan light. 


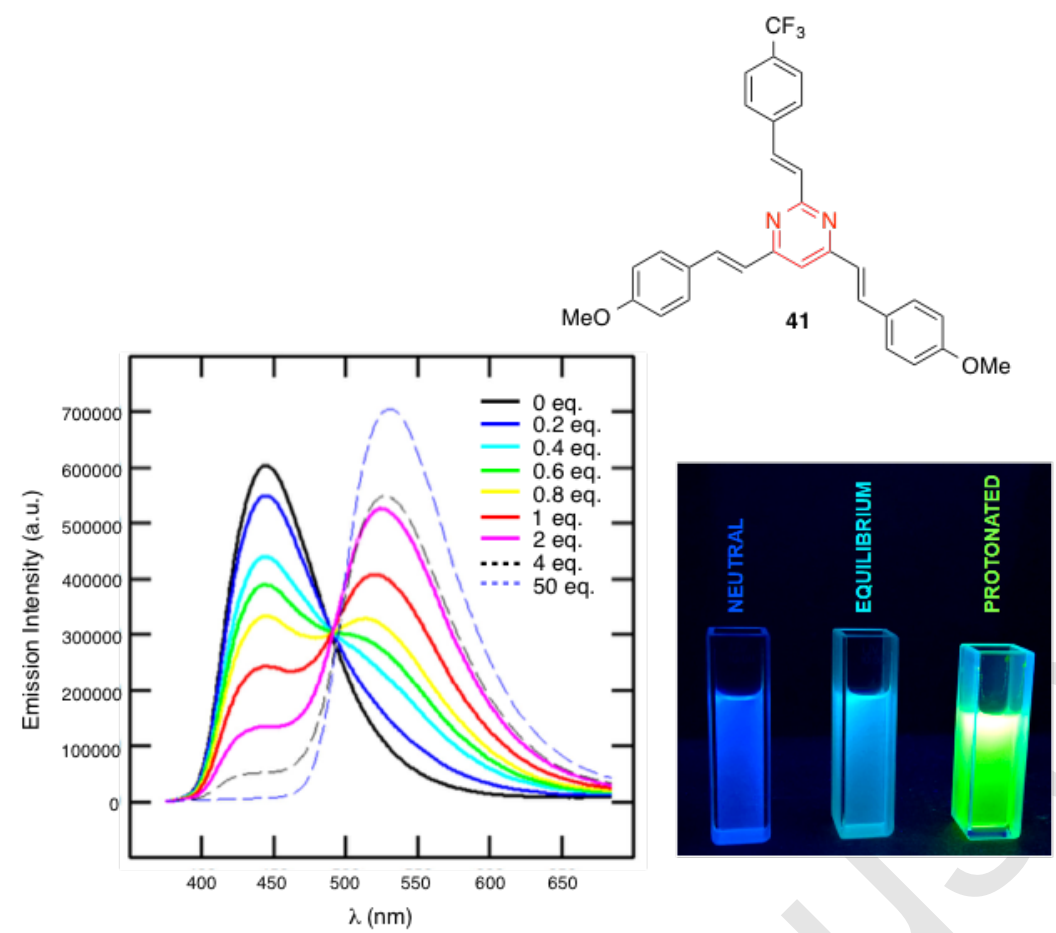

Figure 8. Left: changes in the emission spectra of a $\mathrm{CH}_{2} \mathrm{Cl}_{2}$ solution of $\mathbf{4 1}\left(c=9.64 \times 10^{-6} \mathrm{M}\right)$ upon addition of CSA (0.1-50 equiv). $\lambda_{\text {exc }}=380 \mathrm{~nm}$. Right: changes in the color after addition of 0.8 equiv (middle) and 50 equiv of CSA (right). The pictures were taken in the dark upon irradiation with a hand-held UV lamp $\left(\lambda_{\text {exc }}=366 \mathrm{~nm}\right)$. Adapted with permission from reference [32] (copyright 2018 American Chemical Society).

As previously shown, the emission of amino-substituted pyrimidines is generally (partially) quenched upon protonation. Nevertheless, the presence of weaker electrondonating groups occasionally results in a moderate quenching or even an enhancement of the fluorescence intensity. The fluorescence quantum yields of these compounds are mostly low, but the extension of the $\pi$-conjugated scaffold leads to a significant enhancement of the fluorescence intensity without modifying the solubility properties of the chromophores. Blue emitting neutral forms can be combined with red/orange protonated species to obtain white emitting materials. With this goal, a series of seven methoxy-substituted pyrimidine derivatives 5 (Figure 1), 19 (Figure 2), and 42-46 (Figure 9) with extended $\pi$-conjugated backbones was studied. ${ }^{[25,33]}$ In $\mathrm{CH}_{2} \mathrm{Cl}_{2}$ solution, compound 19 and thiophene derivatives 43 and 45 exhibited low emission quantum yields $\left(\Phi_{\mathrm{F}}<0.04\right)$. Nevertheless, compounds 5, 42, 
44, and 46 are highly emissive in both the neutral $\left(\Phi_{\mathrm{F}}<0.14-0.90\right)$ and protonated forms $\left(\Phi_{\mathrm{F}}\right.$ $<0.15-0.72$ ). The color changes of $\mathrm{CH}_{2} \mathrm{Cl}_{2}$ solutions of 42 and 44 upon gradual addition of TFA are shown in Figure 10. White light emission was observed with chromaticity coordinates of $(0.32,0.36)$ for 42 with 20 equivalents of TFA $\left(\lambda_{\text {exc }}=346 \mathrm{~nm}\right)$ and $(0.33,0.33)$ for 44 with 100 equivalents of TFA $\left(\lambda_{\text {exc }}=355 \mathrm{~nm}\right)$. Fluorophore 5 also exhibited white photoluminescence by controlled protonation both in solution and the solid state when incorporated into a polymer matrix. ${ }^{[33]}$ The emission spectra and the color changes of thin films of polystyrene doped with 1 wt\% of $\mathbf{5}$ in the absence and the presence of TFA, respectively, are shown in Figure 11.

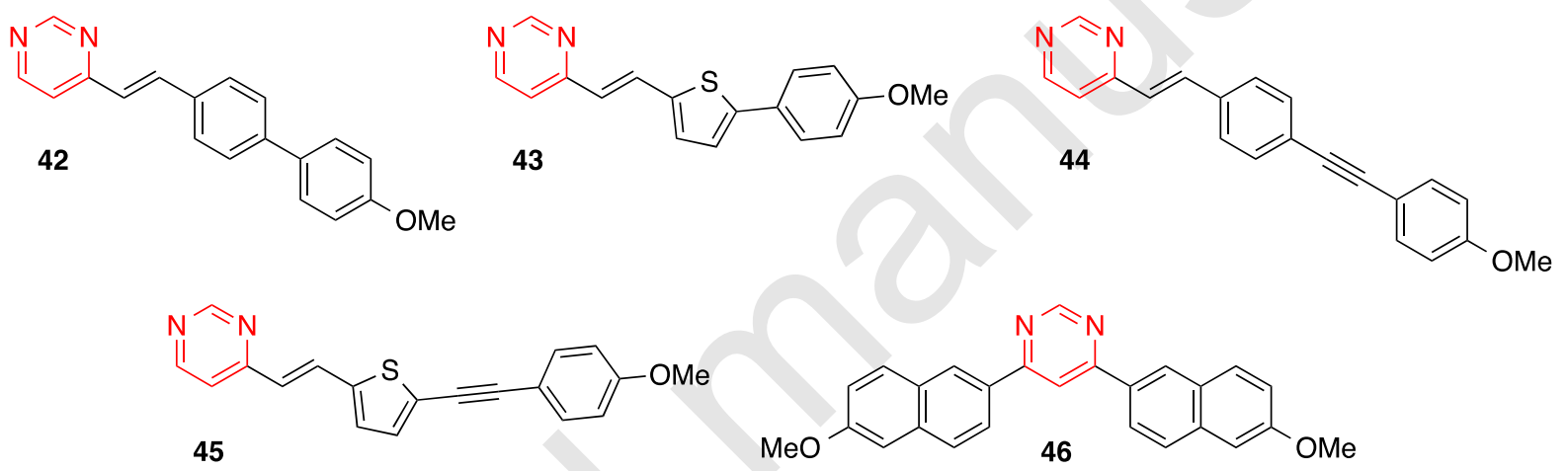

Figure 9. Chemical structures of methoxy derivatives 42-46.
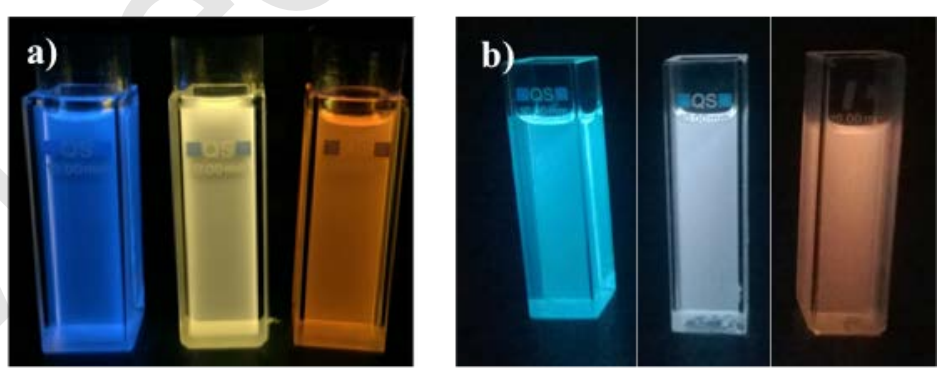

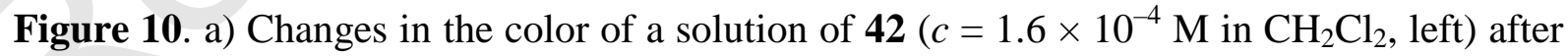
addition of 10 equivalents (middle) and 1000 equivalents (right) of TFA. b) Changes in the color of a solution of $\mathbf{4 4}\left(c=1.2 \times 10^{-5} \mathrm{M}\right.$ in $\mathrm{CH}_{2} \mathrm{Cl}_{2}$, left) after addition of 100 equivalents (middle) and 1000 equivalents (right) of TFA. Photographs were taken upon irradiation with a hand-held UV-lamp $\left(\lambda_{\text {exc }}=366 \mathrm{~nm}\right)$. Reproduced with permission from reference [25] (copyright 2016 American Chemical Society). 


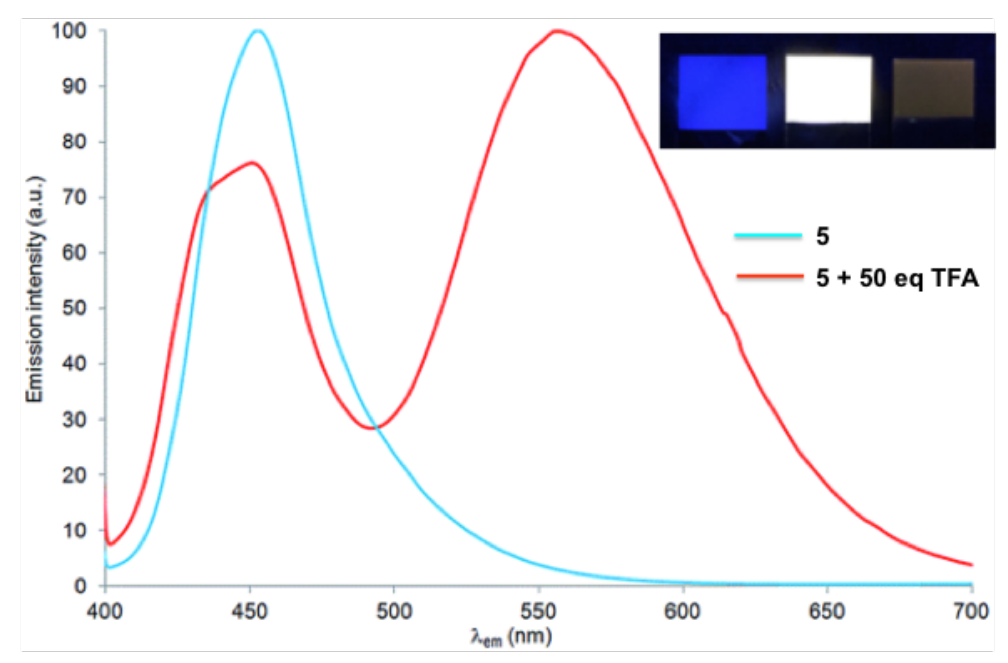

Figure 11. Emission spectra of a polystyrene thin film doped with 1 wt $\%$ of 5 in the absence (blue) and the presence (red, 50 equivalents) of TFA. Inset: Color of the films in the absence (left) and the presence of 50 equivalents (middle) and 1000 equivalents (right) of TFA. Photographs were taken upon irradiation with a hand-held UV-lamp $\left(\lambda_{\text {exc }}=366 \mathrm{~nm}\right)$. Adapted with permission from reference [33] (copyright 2015 Royal Chemical Society).

A series of carbazole- and triphenylamine-substituted pyrimidines 47-52 (Figure 12) was also designed for white light emission. ${ }^{[34]}$ In this case, the shortening of the $\pi$-conjugated scaffold is compensated by the stronger electron-donating character of the carbazolyl and diphenylamino groups with respect to the methoxy group. All of these compounds exhibited an intense purple/blue luminescence in $\mathrm{CH}_{2} \mathrm{Cl}_{2}$ solution with high fluorescence quantum yields (up to 0.86 for $\mathbf{4 9}$ ). Triphenylamine derivatives $\mathbf{4 7 , 4 9}$, and 51 as well as 2-carbazolyl pyrimidine 48 showed almost no luminescence upon addition of camphorsulfonic acid, although 50 and 52 led to intense yellow luminescence under the same conditions $\left(\Phi_{\mathrm{F}}=0.63\right.$ for 50 and $\Phi_{\mathrm{F}}=0.45$ for 52). White light emission both in solution and in solid state was observed by a combination of neutral and protonated forms of 52 (Figure 13). 

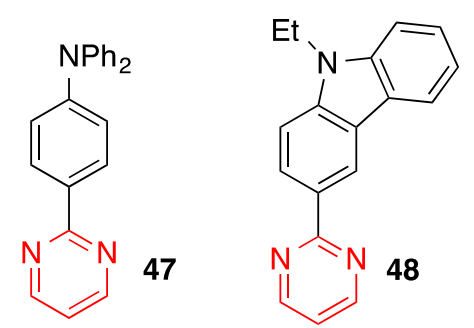<smiles>PN(P)c1ccc(-c2cc(-c3ccc(Nc4ccccc4)cc3)ncn2)cc1</smiles>

49<smiles>CCn1c2ccccc2c2cc(-c3cc(-c4ccc5c(c4)c4ccccc4n5CC)ncn3)ccc21</smiles>

50<smiles></smiles>

51<smiles>CCn1c2ccccc2c2cc(-c3cc(-c4ccc5c(c4)c4ccccc4n5CC)nc(-c4ccc5c(c4)c4ccccc4n5CC)n3)ccc21</smiles>

52

Figure 12. Chemical structures of compounds $47-52$.
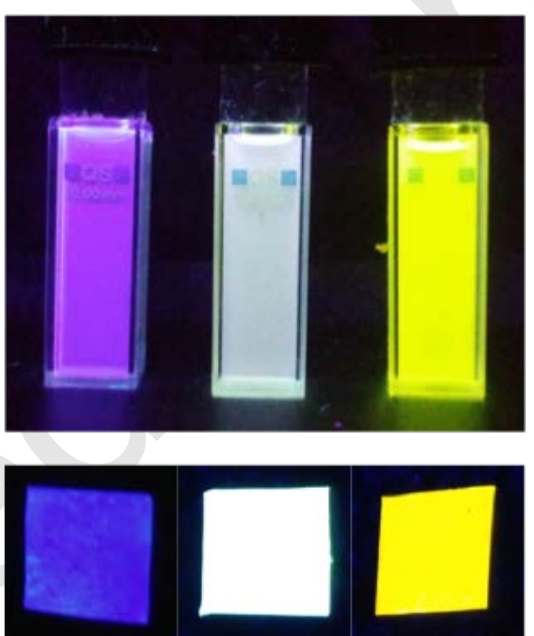

Figure 13. Top: Changes in the color of a solution of $52\left(c=1.25 \times 10^{-5} \mathrm{M}\right.$ in $\mathrm{CH}_{2} \mathrm{Cl}_{2}$, left $)$ after addition of 45 equivalents (middle) and in $10^{-2} \mathrm{M}$ CSA (right). Bottom: Changes in the color of filter paper samples after immersion in a $\mathrm{CH}_{2} \mathrm{Cl}_{2}$ solution of polystyrene doped with 52 (1 wt\%) in the absence (left) and presence of 0.1 equivalents (middle) and 80 equivalents (right) of camphorsulfonic acid. Photographs were taken upon irradiation with a hand-held UV-lamp $\left(\lambda_{\text {exc }}=366 \mathrm{~nm}\right)$. 


\section{Other diazine and benzodiazine chromophores}

Other diazines such as pyrazine $\left(\mathrm{pK}_{\mathrm{a}} \approx 0.65\right)$ and pyridazine $\left(\mathrm{pK}_{\mathrm{a}} \approx 2.3\right)$ and benzodiazines such as quinoxaline $\left(\mathrm{pK}_{\mathrm{a}} \approx 0.56\right)$ and quinazoline $\left(\mathrm{pK}_{\mathrm{a}} \approx 3.5\right)$ are also monobases that can be protonated. ${ }^{[19]}$

Compounds 53-55 (Figure 14) were compared to their pyrimidine analog 19 (Figure 2). ${ }^{[25]}$ All compounds displayed red-shifted absorption upon protonation by TFA. As far as the emission was concerned, the effect of protonation varied according to the nature of the diazine ring. Whereas the progressive addition of acid prompted a color change from blue to green in the emission of pyrimidine 19, the luminescence of pyrazine 54 and quinoxaline 55 was attenuated and ultimately quenched, as illustrated in Figure 15 for a $\mathrm{CH}_{2} \mathrm{Cl}_{2}$ solution of compound 54. In contrast, pyridazine 53 was not luminescent and remained non-emissive after protonation. Theoretical calculations predicted that protonation was favored on the nitrogen atom farthest from the vinyl moiety. The protonated pyridazine derivative $\mathbf{5 3}$ remained non-fluorescent because vanishing overlap occurs between the HOMO located on the methoxynaphthylvinyl moiety and the LUMO centered on the diazine ring. For pyrazine and quinoxaline derivatives $\mathbf{5 4}$ and $\mathbf{5 5}$, the emission was computed to be considerably redshifted to the near IR region where nonradiative decays are well known to be more efficient. Moreover, given that the bright excited state for quinoxaline 55 in the gas phase was envisaged to be destabilized by more than $11 \mathrm{kcal} / \mathrm{mol}$, such nonradiative channels probably explain the fluorescence quenching of this protonated quinoxaline derivative. Nevertheless, some quinoxaline chromophores exhibit a more intense and red-shifted emission after protonation. ${ }^{[24]}$ On the other hand, dimethylamino derivatives 56-58 (Figure 14) displayed blue-shifted absorption due to the protonation of the amino group. ${ }^{[24]}$ 
<smiles>COc1ccc2cc(/C=C/c3cccnn3)ccc2c1</smiles>

53<smiles>CN(C)c1ccc(/C=C/c2cccnn2)cc1</smiles><smiles>COc1ccc2cc(/C=C/c3cnccn3)ccc2c1</smiles>

54<smiles>[B]C(=O)c1ccc(N(C)C)cc1</smiles><smiles>COc1ccc2cc(/C=C/c3cnc4ccccc4n3)ccc2c1</smiles>

55<smiles>CN(C)c1ccc(/C=C/c2cnc3ccccc3n2)cc1</smiles>

Figure 14. Chemical structures of compounds 53-58.

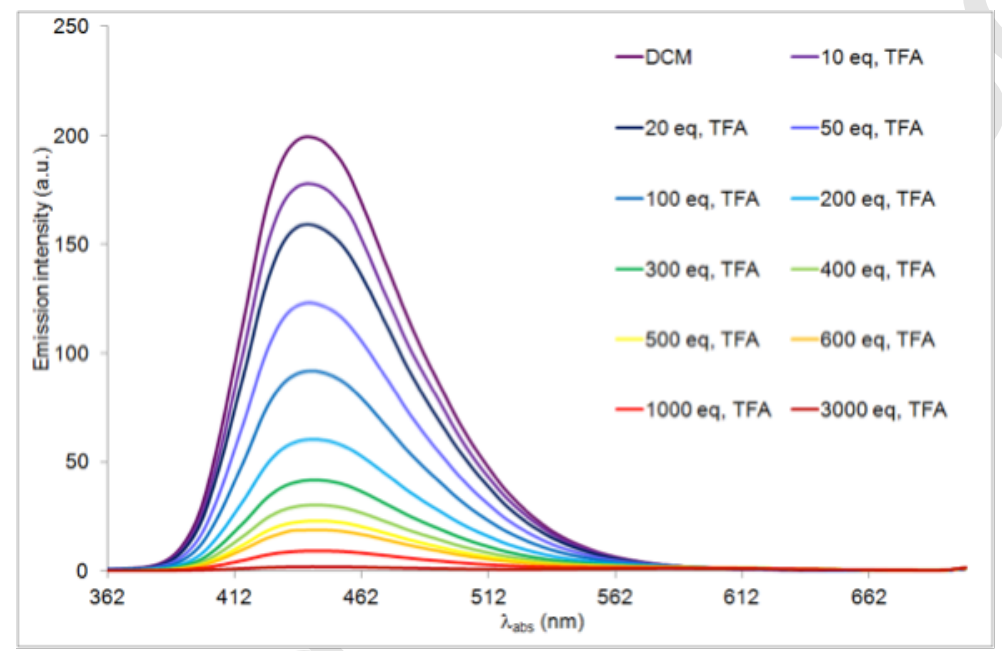

Figure 15. Changes in the emission spectra of a $\mathrm{CH}_{2} \mathrm{Cl}_{2}$ solution of 54 upon addition of TFA (10-30000 equiv), $\lambda_{\text {exc }}=352 \mathrm{~nm}$. Reproduced with permission from reference [25] (copyright 2016 American Chemical Society).

The effect of protonation on the photophysical properties of a series of aminosubstituted quinazoline chromophores 59-63 (Figure 16) has been also studied. ${ }^{[35]}$ In all cases, a red-shifted absorption, as evidenced by the significant color change experienced by their $\mathrm{CH}_{2} \mathrm{Cl}_{2}$ solutions (Figure 17), associated with total emission quenching was observed. It would be interesting to study the effect of protonation with other quinazolines substituted by weaker electron-donating fragments, such as methoxy or carbazolyl groups. 


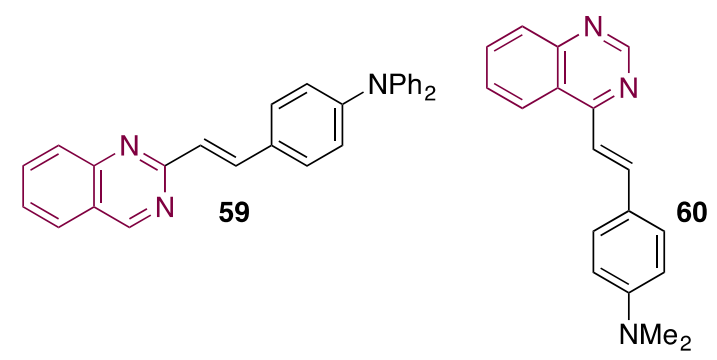<smiles>CN(C)c1ccc(-c2ncnc3ccccc23)cc1</smiles>
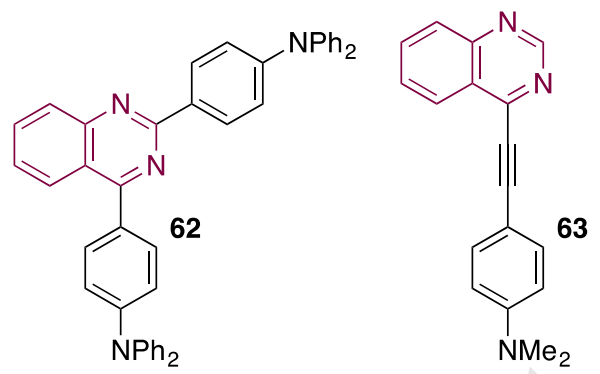

Figure 16. Chemical structures of compounds 59-63.

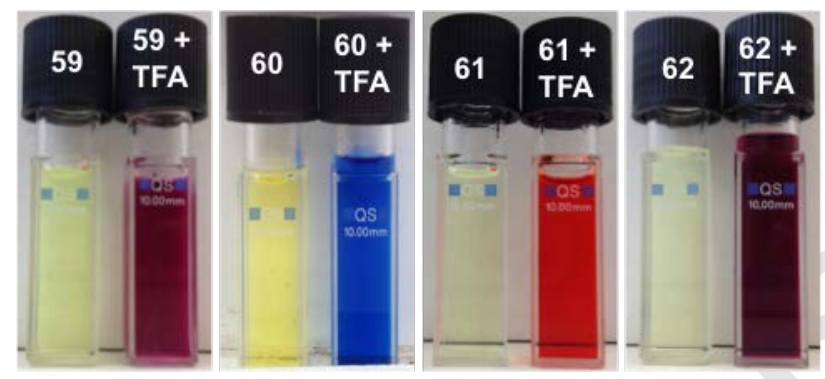

Figure 17. Color change of $\mathrm{CH}_{2} \mathrm{Cl}_{2}$ solutions of several quinazoline derivatives in the presence of TFA. Adapted with permission from reference [35] (copyright 2014 American Chemical Society).

\section{Pyridine chromophores}

Pyridine $\left(\mathrm{pK}_{\mathrm{a}} \approx 5.2\right)$ is a stronger base than (benzo)diazines. The use of this basic heterocyclic compound allows easy control of the acid-base equilibrium with the aim of obtaining white luminescence. As the pyridine ring has a weaker electron-withdrawing character than pyrimidine, the methoxy or carbazole substituents were replaced by stronger electron-donating triphenylamino groups. Thus, a series of triphenylamine derivatives bearing pyridine units 64-70 was designed (Figure 18). ${ }^{[36]}$ Likewise, the corresponding trifluoroacetate salts were isolated and characterized. For all series of compounds, the gradual addition of TFA to $\mathrm{CHCl}_{3}$ solutions led to the progressive disappearance of both of the absorption and emission bands and the appearance of a new red-shifted absorption/emission band. As an example, the changes for compound $\mathbf{7 0}$ are represented in Figure 19. Timeresolved emission studies performed on compounds 67-69 revealed an energy transfer from the neutral to the protonated species on the 1 ps time scale. ${ }^{[37]}$ As expected, a substantial 
increase in the positive emission solvatochromic behavior for 64 was observed when protonated, which is consistent with a significant enhancement of the ICT in the acidified form. For all compounds, the controlled protonation of the blue emitting pyridine derivatives led to white photoluminescence in solution due to the formation of yellow/orange emissive pyridinium species (Figure 20, top). The chromaticity coordinates were close to those of pure white light $(0.33,0.33)$. Doped polystyrene thin films of compounds 64 and $\mathbf{7 0}$ were also prepared using different ratios of neutral and protonated forms. Unfortunately, although the films remained luminescent, it was not possible to obtain white light in the solid state. When compound 64 was used both the absorption and the emission band experienced a significant blue shift with regard to the $\mathrm{CHCl}_{3}$ solution, and the chromaticity coordinates were far from those of pure white light. Multi-color photoluminescence was achieved by tuning the ratio of the pyridine/pyridinium forms in the case of fluorophore $\mathbf{7 0}$ (Figure 20, bottom).
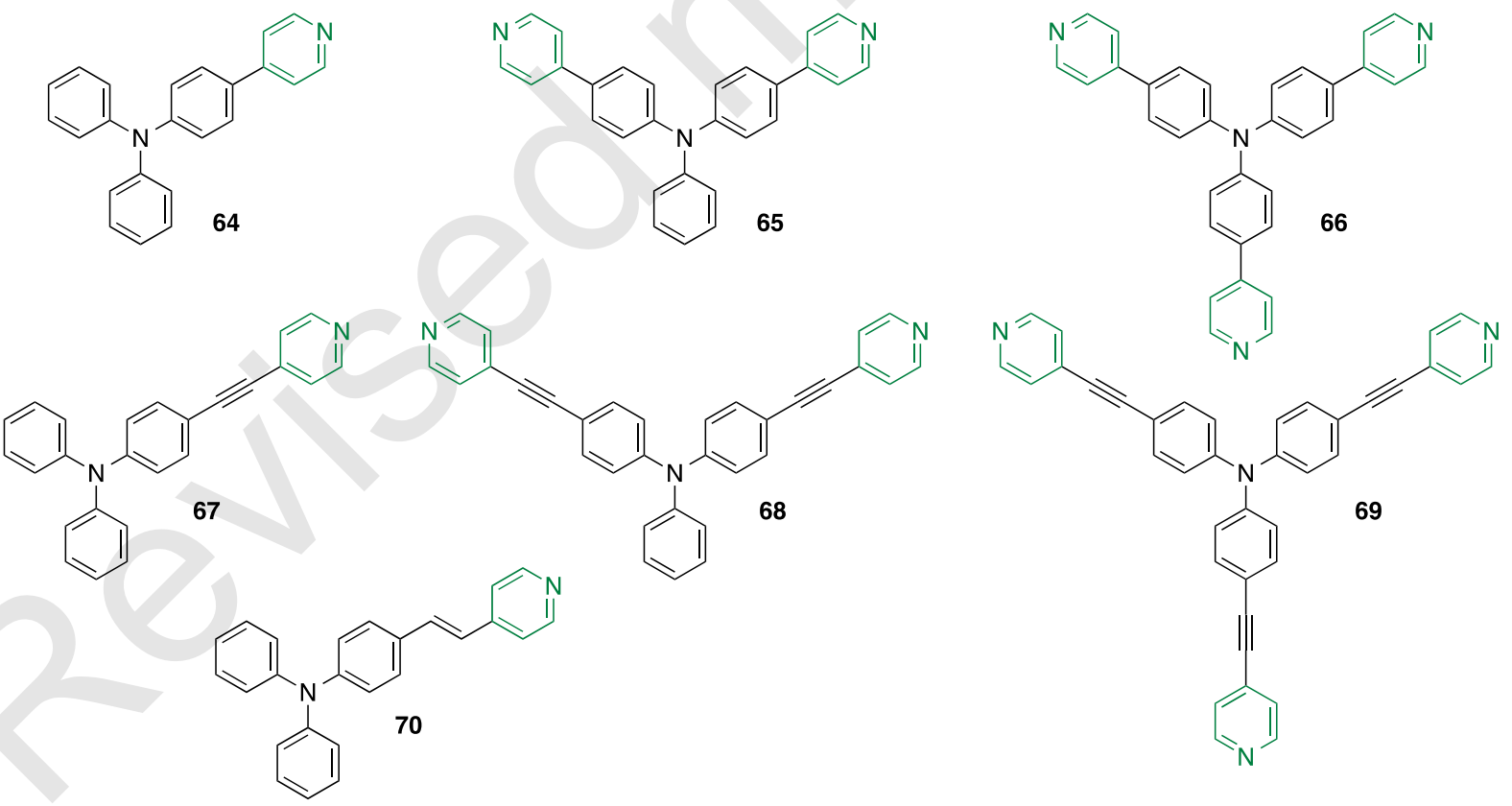

Figure 18. Chemical structures of pyridine derivatives 64-70. 

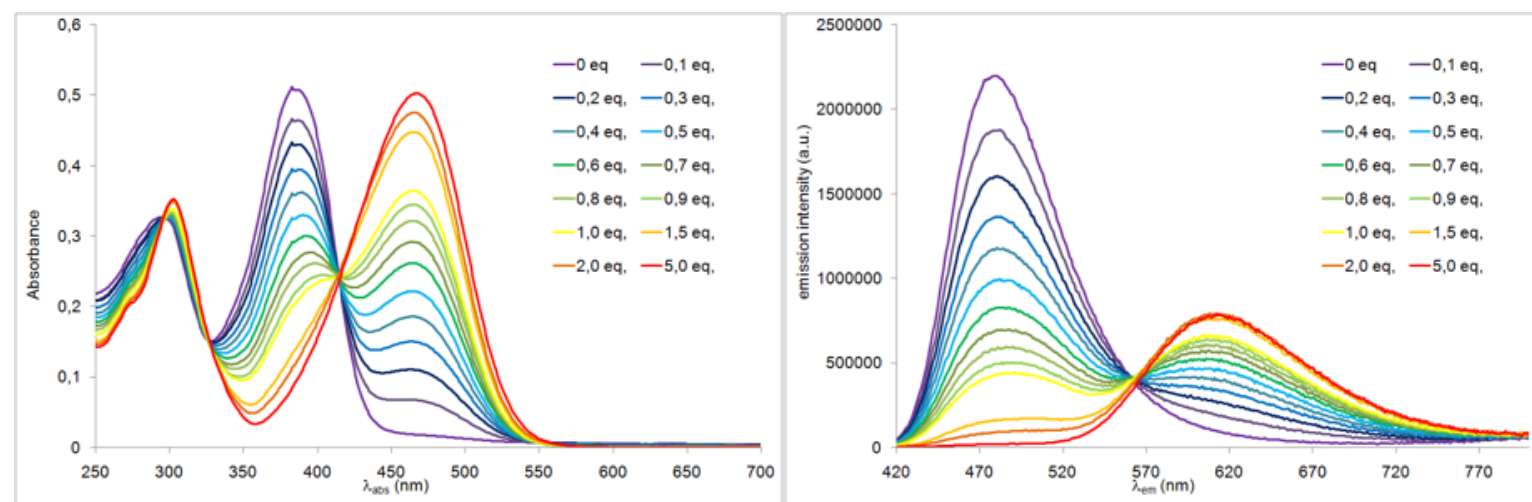

Figure 19. Changes in the absorption (left) and emission spectra (right) of a $\mathrm{CHCl}_{3}$ solution of $70\left(c=1.86 \times 10^{-5} \mathrm{M}\right)$ upon addition of TFA (0.1-5.0 equivalents). Reproduced with permission from reference [36] (copyright 2017 Elsevier).

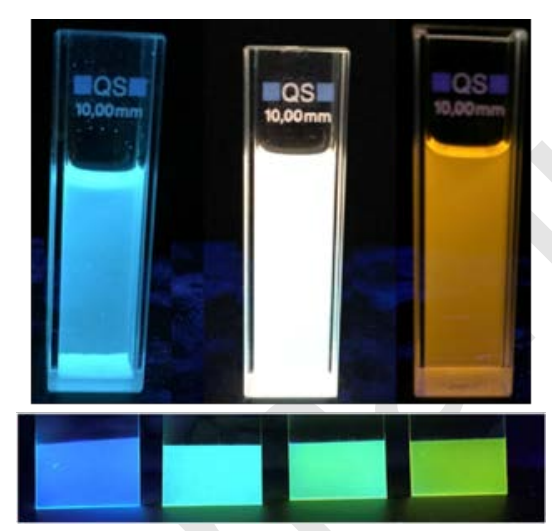

Figure 20. Top: changes in the color of a $\mathrm{CHCl}_{3}$ solution of $\mathbf{7 0}\left(c=1.86 \times 10^{-5} \mathrm{M}\right)$ after the addition of 0.8 equivalents (middle) and 5 equivalents of TFA (right). Bottom: colors of polystyrene thin films of $\mathbf{7 0}(1 \mathrm{wt} \%)$ in the absence and the presence of $0.4,0.6$, and 5 equivalents of TFA (from left to right). Photographs were taken upon irradiation with a handheld UV-lamp $\left(\lambda_{\text {exc }}=366 \mathrm{~nm}\right.$ ). Adapted with permission from reference [36] (copyright 2017 Elsevier).

In order to overcome this problem, the reinforcement of the electron-donating character of the triphenylamine was tested by the introduction of methoxy, carbazolyl or methoxythienyl fragments at the triphenylamine core (compounds 71-76, Figure 21). Unfortunately, the protonated forms of these chromophores were not emissive in any case. ${ }^{\text {[38] }}$ 

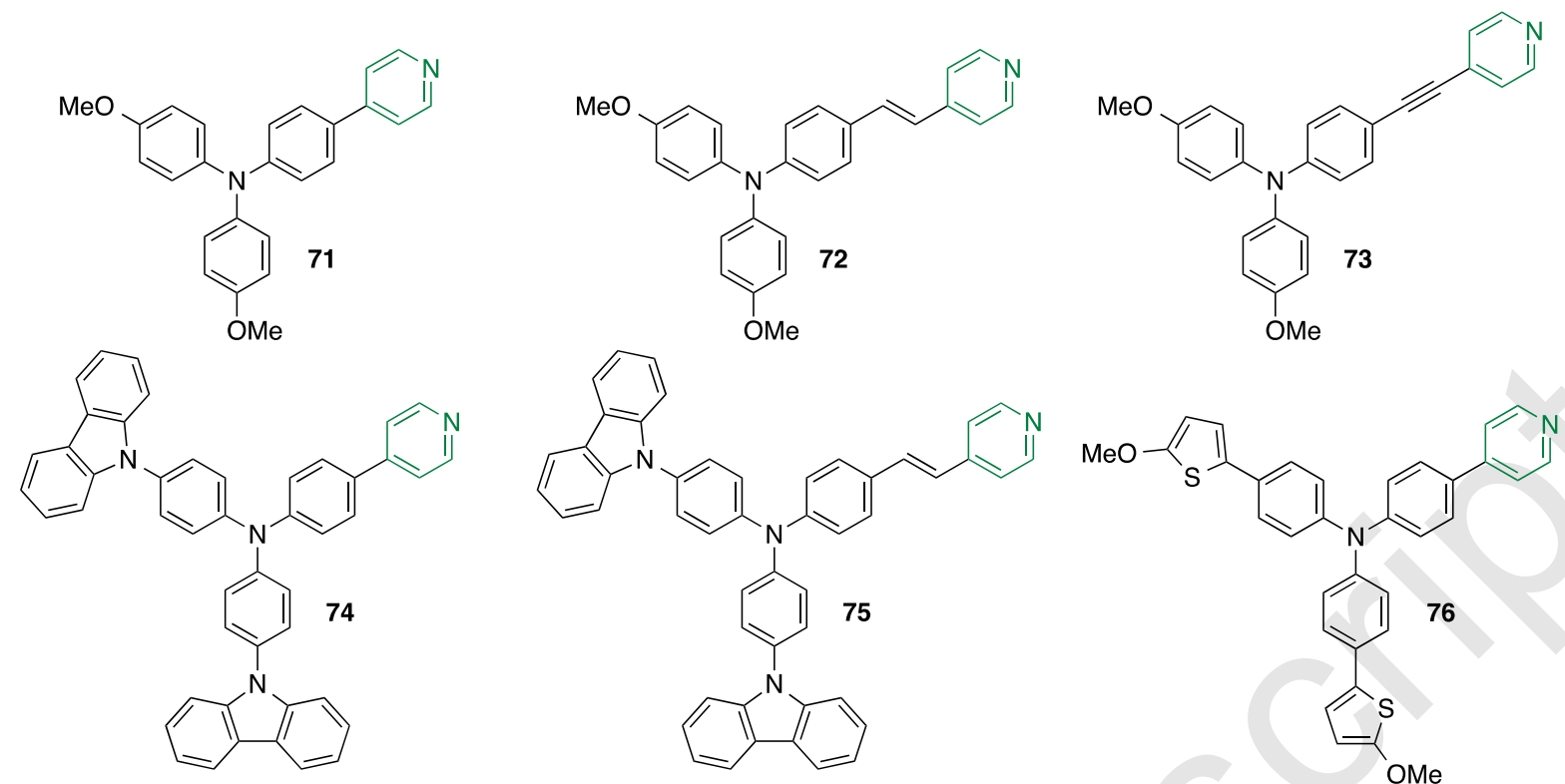

Figure 21. Chemical structures of compounds 71-76.

\section{Conclusions}

The extraordinary optical properties of $\pi$-extended push-pull molecules that incorporate azaheterocyclic rings as electron-withdrawing moieties provide an important tool to develop new sensing and luminescent materials. In the last year, we have prepared and studied a large library of such chromophores through a fruitful collaborative 'French-SpanishCzech’ project. In this review we have illustrated the effect that the addition of acid has on the photophysical properties of these materials. White light photoluminescence can be obtained by controlled protonation, which involves an equilibrium between two different forms of complementary emitting colors. Nevertheless, major efforts are still required to harness the full potential of these compounds.

\section{Acknowledgments}

The authors wish to thank all those individuals who have been involved in the different stages of the work described in the manuscript. Funding by the Junta de Comunidades de Castilla-La Mancha/FEDER (project SBPLY/17/180501/000214) and the Ministerio de Economía y Competitividad/Agencia Estatal de Investigación/FEDER (project CTQ2017-84561-P) is also gratefully acknowledged. F.B. is particularly indebted to the 
European Regional Development Fund-Project "Organic redox couple based batteries for energetics of traditional and renewable resources (ORGBAT)" No. CZ.02.1.01/0.0/0.0/16_025/0007445.

\section{References}

[1] F. Bureš, RSC Adv. 2014, 4, 58826-58851.

[2] K. Melánová, D. Cvejn, F. Bureš, V. Zima, J. Svoboda, L. Beneš, T. Mikysek, O. Pytela, P. Knotek, Dalton Trans. 2014, 43, 10462-10470.

[3] E. V. Nosova, S. Achelle, G. N. Lipunova, V. N. Charushin, O. N. Chupakhin, Russ. Chem. Rev. 2019, 88, 1128-1178.

[4] S. Achelle, N. Plé, A. Turck, RSC Adv. 2011, 1, 364-388.

[5] (a) S. Achelle, N. Plé, Curr. Org. Synth. 2012, 9, 163-187; (b) S. Achelle, J. RodríguezLópez, F. Robin-le Guen, ChemistrySelect 2018, 3, 1852-1886; (c) G. N. Lipunova, E. V. Nosova, V. N. Charushin, O. N. Chupakhin, Curr. Org. Synth. 2018, 15, 793-814.

[6] S. Achelle, C. Baudequin, N. Plé, Dyes Pigm. 2013, 98, 575-600.

[7] (a) S. S. M. Fernandes, M. M. M; Raposo, The 19th International Electronic Conference on Synthetic Organic Chemistry, 2015. DOI: 10.3390/ecsoc-19-a020. (b) S. S. M. Fernandes, M. M. M; Raposo, The 21st International Electronic Conference on Synthetic Organic Chemistry, 2017. DOI: 10.3390/ecsoc-21-04797.

[8] C. Bonaccorso, A. Cesaretti, F. Elisei, L. Mencaroni, A. Spalletti, C. G. Fortuna, ChemPhysChem 2018, 19, 1917-1929.

[9] (a) M. Tromayer, P. Gruber, A. Rosspeintner, A. Ajami, W. Husinsky, F. Plasser, L. González, E. Vauthey, A. Ovsianikov, R. Liska, Sci. Rep. 2018, 8, 17273; (b) Z.-B. Cai, L.-F. Liu, M. Zhou, B. Li, Y. Chen, Dyes Pigm. 2014, 102, 88-93; (c) J. Hu, Y. Li, H. Zhu, S. Qiu, G. He, X. Zhu, A. Xia, ChemPhysChem 2015, 16, 2357-2365.

[10] G. Clavier, P. Audebert, Chem. Rev. 2010, 110, 3299-3314. 
[11] M. Klikar, P. Solanke, J. Tydlitát, F. Bureš Chem. Rec. 2016, 16, 1886-1905.

[12] (a) Y. Shiraishi, C. Ichimura, S. Sumiya, T. Hirai, Chem. Eur. J. 2011, 17, 8324-8332;

(b) S. Hayashi, A. Asano, T. Koizumi, Polym. Chem. 2011, 2, 2764-2766; (c) K. Yamaguchi, T. Murai, J.-D. Guo, T. Sasamori, N. Tokitoh, Chem. Open 2016, 5, 434-438.

[13] (a) S. Achelle, S. Khalal, A. Barsella, J.-Y.; Saillard, X. Che, J. Vallet, F. Bureš, B. Caro, F. Robin-le Guen, Dyes Pigm. 2015, 113, 562-570; (b) M. A. Ramírez, A. M. Cuadro, J. Alvarez-Builla, O. Castaño, J. L. Andrés, F. Mendicuti, K. Clays, I. Asselberghs, J. J. Vaquero, Org. Biomol. Chem. 2012, 10, 1659-1669.

[14] (a) M. Kondo, K. Okuomoto, S. Miura, T. Nakanishi, J.-i. Nishida, T. Kawase, N. Kawatsuki, Chem. Lett. 2017, 46, 1179-1181; (b) M. Li; Y. Yuan, Y. Chen, ACS Appl. Mater. Interfaces 2018, 10, 1237-1243; (c) C. Wink, H. Detert, J. Phys. Org. Chem. 2013, 26, 144150; (c) S.-i. Kato, Y. Yamada, H. Hiyoshi, K. Umezu, Y. Nakamura, J. Org. Chem. 2015, 80, 9076-9090; (d) H. Muraoka, T. Obara, S. Ogawa, Phosphorus Sulfur Silicon Relat. Elem. 2019, 194, 726-730; (e) A. Mukhopadhyay, A. K.; Mishra, K. Jana, J. N. Moorthy, J. Photochem. Photobiol A 2017, 347, 199-208; (f) S. Manickam, U. Balijapalli, S. Sawminathan, P. Samuelrajamani, S. Kamaraj, V. Shanmugam, S. Ramalingam, S. Kulathu lyer, Eur. J. Org. Chem. 2018, 6204-6216.

[15] (a) V. Schmitt, S. Moschel, H. Detert, Eur. J. Org. Chem. 2013, 5655-5669; (b) R. Tang, X. Wang, W. Zhang, X. Zhuang, S. Bi, W. Zhang, F. Zhang, J. Mater. Chem. C 2016, 4, 7640-7648; (c) Z. Yang, W. Qin, J. W. Y. Lam, S. Chen, H. H. Y. Sung, I. D. Williams, B. Z. Tang, Chem. Sci. 2013, 4, 3725-3730; (d) B. Wang, C. Wei, RSC Adv. 2018, 8, 22806-22812. [16] (a) E. Cariati, C. Dragonetti, E. Lucenti, F. Nisic, S. Righetto, D. Roberto, E. Tordin, Chem. Commun. 2014, 50, 1608-1610; (b) E. Cariati, C. Botta, S. G. Danelli, A. Forni, A. Giaretta, U. Giovanella, E. Lucenti, D. Marinotto, S. Righetto, R. Ugo, Chem. Commun. 2014, 50, 14225-14228; (c) E. Lucenti, A. Forni, D. Marinotto, A. Previtali, S. Righetto, E. 
Cariati, Inorganics, 2019, 7, 38; (d) C. Coluccini, M. Caricato, E. Cariati, S. Righetto, A. Forni, D. Pasini, RSC Adv. 2015, 5, 21495-21503.

[17] U. Giovanella, E. Cariati, E. Lucenti, M. Pasini, F. Galeotti, C. Botta, ChemPhysChem 2017, 18, 2157-2161.

[18] (a) D. Liu, Z. Zhang, H. Zhang, Y. Wang, Chem. Commun. 2013, 49, 10001-10003; (b) K. Yamaguchi, T. Murai, J.-D. Guo, T. Sasamori, N. Tokitoh, Chem. Open 2016, 5, 434-438. [19] R. Milcent, Chimie Organique Hétérocyclique, EDP Science, Les Ulis 2003, p. 605.

[20] S. Achelle, Y. Ramondenc, F. Marsais, N. Plé, Eur. J. Org. Chem. 2008, 3129-3140.

[21] S. Achelle, I. Nouira, B. Pfaffinger, Y. Ramondenc, N. Plé, J. Rodríguez-López, J. Org. Chem. 2009, 74, 3711-3717.

[22] S. Achelle, J. Rodríguez-López, F. Bureš, F. Robin-le Guen, Dyes Pigm. 2015, 121, 305311.

[23] C. Hadad, S. Achelle, J. C. García-Martínez, J. Rodríguez-López, J. Org. Chem. 2011, 76, 3837-3845.

[24] S. Achelle, A. Barsella, C. Baudequin, B. Caro, F. Robin-le Guen, J. Org. Chem. 2012, 77, 4087-4096.

[25] S. Achelle, J. Rodríguez-López, C. Katan, F. Robin-le Guen, J. Phys. Chem. C 2016, 120, 26986-26995.

[26] S. Achelle, F. Robin-le Guen, Tetrahedron Lett. 2013, 54, 4491-4496.

[27] D. Cvejn, S. Achelle, O. Pytela, J.-P. Malval, A. Spangenberg, N. Cabon, F. Bureš, F. Robin-le Guen, Dyes Pigm. 2016, 124, 101-109.

[28] A. I. Aranda, S. Achelle, F. Hammerer, F. Mahuteau-Betzer, M.-P. Teulade-Fichou, Dyes Pigm. 2012, 95, 400-407.

[29] S. Achelle, L. Bodiou, J. Charrier, F. Robin-le Guen, C. R. Chimie 2016, 19, 279-285. 
[30] S. Achelle, S. Kahlal, J.-Y. Saillard, N. Cabon, B. Caro, F. Robin-le Guen, Tetrahedron, 2014, 70, 2804-2815.

[31] L. Vurth, C. Hadad, S. Achelle, J. C. García-Martínez, J. Rodríguez-López, O. Stéphan, Colloid Polym. Sci. 2012, 290, 1353-1359.

[32] M. Fecková, P. le Poul, F. Robin-le Guen, T. Roisnel, O. Pytela, M. Klikar, F. Bureš, S. Achelle, J. Org. Chem. 2018, 83, 11712-11726.

[33] S. Achelle, J. Rodríguez-López, N. Cabon, F. Robin-le Guen, RSC Adv. 2015, 5, 107396107399.

[34] S. Achelle, J. Rodríguez-López, M. Larbani, R. Plaza-Pedroche, F. Robin-le Guen, Molecules 2019, 24, 1742.

[35] S. Achelle, J. Rodríguez-López, F. Robin-le Guen, J. Org. Chem. 2014, 79, 7564-7571.

[36] J. Tydlitát, S. Achelle, J. Rodríguez-López, O. Pytela, T. Mikýsek, N. Cabon, F. Robin-le Guen, D. Miklík, Z. Růžičková, F. Bureš, Dyes Pigm. 2017, 146, 467-478.

[37] F. Kournoutas, K. Seintis, N. Karakostas, J. Tydlitát, S. Achelle, G. Pistolis, F. Bureš, M. Fakis, J. Phys. Chem. A 2019, 123, 417-428.

[38] J. Tydlitát, M. Fecková, P. Le Poul, O. Pytela, M. Klikar, J. Rodríguez-López, F. Robinle Guen, S. Achelle, Eur. J. Org. Chem. 2019, 1921-1930. 